\title{
MORPHOMETRIC STUDY OF FRONTAL HORN OF LATERAL VENTRICLE BY COMPUTERISED TOMOGRAPHY
}

\section{Shaikh Shamama Farheen ${ }^{* 1}$, S B Sukre ${ }^{2}$.}

${ }^{* 1}$ Assistant Professor, Department of Anatomy,Government Medical College Aurangabad, Maharashtra, India.

2 Professor and Head, Department of Anatomy,Government Medical College Aurangabad, Maharashtra, India.

\section{ABSTRACT}

Aims and Objectives: To analyze morphometrically the length frontal horn of normal lateral ventrical of human brain and to study, if any, sex difference and/ or side difference in the length.

Material and Methods: Five hundred (500) normal CT scans of patients in the age group of 20-79 years were taken. The study group included 250 males and 250 females. Length of frontal horn of right lateral ventricle in millimeters were taken from interventricular foramen to the tip of frontal horn on both sides.

Results: The data analysis showed that the length of frontal horns were found to be more in males and on left side. Conclusion: The present study defined the length of frontal horn of lateral ventricles of brain by CT which could have clinical correlations in diagnosis, treatment and management of neurological conditions.

KEY WORDS: Morphometry, Ventricles, human brain, CT Scan, Frontal horn, Interventricular foramen.

Address for Correspondence: Dr. Shaikh Shamama Farheen, Assistant Professor, Department of Anatomy, Government Medical College Aurangabad, Maharashtra, India.

E-Mail: shamamashadab@gmail.com

\begin{tabular}{|c|c|c|}
\hline \multicolumn{3}{|c|}{ Access this Article online } \\
\hline \multirow{2}{*}{ Quick Response code } & \multicolumn{2}{|c|}{$\begin{array}{l}\text { Web site: International Journal of Anatomy and Research } \\
\qquad \text { ISSN 2321-4287 } \\
\text { www.ijmhr.org/ijar.htm }\end{array}$} \\
\hline & $\begin{array}{l}\text { Received: } 07 \text { May } 2017 \\
\text { Peer Review: } 08 \text { May } 2017\end{array}$ & $\begin{array}{l}\text { Accepted: } 18 \text { Jun } 2017 \\
\text { Published (O): } 31 \text { Jul } 2017\end{array}$ \\
\hline DOI: $10.16965 /$ ijar.2017.250 & Revised: None & Published (P): 31 Jul 2017 \\
\hline
\end{tabular}

\section{INTRODUCTION}

The cerebral ventricular system consists of a series of interconnecting spaces and channels which originate from the central lumen of embryonic neural tube. It comprises of a large space present in each cerebral hemisphere as lateral ventricle, a slit like space in between diencephalon called third ventricle and a space present between the pons and medulla anteriorly and cerebellum posteriorly called as fourth ventricle. This cerebrospinal fluid filled ventricular system is an essential part of the brain [1]. Understanding the normal and abnormal anatomy of the ventricular system of the brain is helpful for clinicians, neurosurgeons and radiologists in day-to-day practice [2].
The largest of all the ventricles, Lateral ventricle is divided into a body and anterior (frontal), posterior (occipital) and inferior (temporal) horns. The anterior horn lies within the frontal lobe, bounded anteriorly by the posterior aspect of the genu and rostrum of the corpus callosum. Anterior horns of the two lateral ventricles are separated by the septum pellucidum. Coronal profile of the anterior horn is roughly that of a flattened triangle in which the rounded head of caudate nucleus forms the lateral wall and floor. Morphometric analysis of cerebral ventricular system is important for evaluating changes due to growth, ageing, intrinsic and extrinsic pathologies [3]. Morphometric analysis of brain structures such as volume, shape and size of 
ventricular system especially, the frontal horn of lateral ventricle, has become a focus of interest in neuropsychiatric disorders like schizophrenia and Alzheimers disease [4]. Similarly morphometric analysis of ventricular system helps neurosurgeons for localization and total removal of space occupying lesions like craniopharyngiomas and gliomas. There will be alteration in brain morphology,size and shape of ventricular system in chronic alcoholism [5].

Computerised Axial tomography is a safe non-invasive technique which can be utilized for morphometrical evaluation of the ventricles [6]. The present work was undertaken to analyse the frontal horn of lateral ventricles of brain by CT scan method.

\section{MATERIALS AND METHODS}

Data for the present study was collected from the CT scans performed in the Department of Radiology, Government Medical College and Hospital Aurangabad. CT scans reported as normal by radiologists were selected. Five hundred (500) normal CT scans of patients in the age group of 20-79 years were taken. The study group included 250 males and 250 females.

Fig. 1: CT scan at the level of interventricular foramen showing parts of lateral ventricle 1-2: Length of Frontal horn of Lateral ventricle

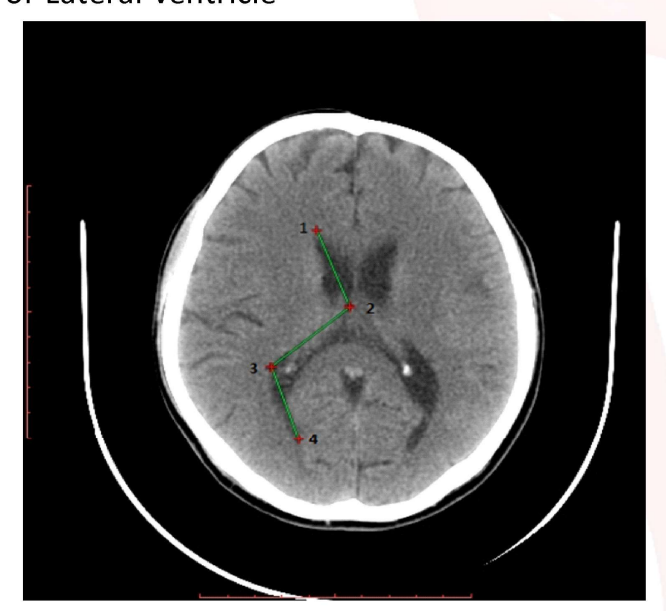

Inclusion criteria: $\mathrm{CT}$ scans of patients between 20-79 years age group with normal radiological findings.

Exclusion Criteria: CT scans of patients, with history of head injuries, previous intracranial surgeries or showing local mass lesion or cerebral infractions, were excluded from the study.

The computerised tomography films were taken and measurements were taken at the level of interventricular foramen of Monro:

Length of frontal horn of right lateral ventricle in millimeters were taken from interventricular foramen to the tip of frontal horn on both sides.

\section{OBSERVATION AND RESULT}

In the present study 500 normal CT scans $\{250$ males and 250 females $\}$ in the age group of 20-79 years were studied.

Length Of Frontal Horn : The mean length of frontal horn in males were found to be $28.5 \mathrm{~mm}$ and $30.3 \mathrm{~mm}$ on right and left sides respectively, while in females it was found to be $25.9 \mathrm{~mm}$ and $29.6 \mathrm{~mm}$ on right and left sides respectively. Though the mean length of frontal horn was more in males than that in females and more on the left side as compared to the right, the differences were not found to be statistically significant (Table 1).

Table 1: Showing genderwise mean length and SD of frontal horn on right and left sides.

\begin{tabular}{|c|c|c|c|c|}
\hline \multirow{2}{*}{} & \multicolumn{4}{|c|}{ SEX } \\
\cline { 2 - 5 } & \multicolumn{2}{|c|}{ MALE(250) } & \multicolumn{2}{|c|}{ FEMALE(250) } \\
\cline { 2 - 5 } & Mean & $\begin{array}{l}\text { Standard } \\
\text { Deviation }\end{array}$ & Mean & $\begin{array}{c}\text { Standard } \\
\text { Deviation }\end{array}$ \\
\hline Right & 28.5 & 1.06 & 25.9 & 1.46 \\
\hline Left & 30.3 & 1.46 & 29.7 & 1.22 \\
\hline
\end{tabular}

Age wise analysis showed that the mean length of frontal horn increased gradually from age group 30-39 yr onwards with a maximum value in age group 70-79 $\mathrm{yr}$ on right and left sides (Table: 3).Also the mean length of left frontal horn was found to be more than that of the right frontal horn and mean lengths of both, left and right frontal horns, increased gradually with increasing age (Table: 3).On application of ANOVA no statistically significant difference was found between any of the age groups. $(p>0.05)$ (Table 2, 3 and 3a).

Table 2: Showing mean lengths and SD of frontal horn on right and left sides in various age groups:

\begin{tabular}{|c|c|c|c|c|c|}
\hline \multicolumn{2}{|c|}{} & \multicolumn{4}{|c|}{ FRONTAL HORN } \\
\hline \multirow{2}{*}{ Age group } & \multicolumn{2}{|c|}{ RIGHT(500) } & \multicolumn{2}{c|}{ LEFT(500) } \\
\hline \multirow{5}{*}{$\begin{array}{c}\text { Mean } \\
\text { (mm) }\end{array}$} & $\begin{array}{c}\text { Standard } \\
\text { Deviation }\end{array}$ & $\begin{array}{c}\text { Mean } \\
(\mathrm{mm})\end{array}$ & $\begin{array}{c}\text { Standard } \\
\text { Deviation }\end{array}$ \\
\cline { 2 - 6 } & 20 to 29 & 27.2 & 1.92 & 29.7 & 1.38 \\
\cline { 2 - 6 } & 30 to 39 & 27.3 & 1.76 & 30.1 & 1.27 \\
\cline { 2 - 6 } & 40 to 49 & 27.3 & 1.79 & 30.2 & 1.52 \\
\cline { 2 - 6 } & 50 to 59 & 27.4 & 1.89 & 29.7 & 1.34 \\
\cline { 2 - 6 } & 60 to 69 & 27.6 & 1.36 & 29.9 & 1.03 \\
\cline { 2 - 6 } & 70 to 79 & 28.1 & 1.56 & 30.3 & 1.74 \\
\hline
\end{tabular}


Table 3: Showing "ANOVA" for Right Frontal Horn.

\begin{tabular}{|c|c|c|c|c|c|}
\hline \multicolumn{7}{|c|}{ Right Frontal Horn } \\
\hline & $\begin{array}{c}\text { Sum of } \\
\text { Squares }\end{array}$ & $\begin{array}{c}\text { Df } \\
\text { (Degrees of } \\
\text { freedom) }\end{array}$ & $\begin{array}{c}\text { Mean } \\
\text { Square }\end{array}$ & F value & P value. \\
\hline Between Groups & 9.535 & 6 & 1.589 & 0.48 & 0.823 \\
\hline Within Groups & 1631.993 & 493 & 3.31 & 0.471 & 0.65 \\
\hline Total & 1641.528 & 499 & 4.899 & 0.951 & 1.473 \\
\hline
\end{tabular}

Table 3a: Showing "ANOVA" for Left Frontal Horn.

Table 4: Showing the length of frontal horn in the present study.

\begin{tabular}{|c|c|c|c|c|c|}
\hline \multicolumn{6}{|c|}{ ANOVA } \\
\hline & $\begin{array}{c}\text { Sum of } \\
\text { Squares }\end{array}$ & $\begin{array}{c}\text { Df } \\
\text { (Degrees of } \\
\text { freedom) }\end{array}$ & $\begin{array}{c}\text { Mean } \\
\text { Square }\end{array}$ & F Value & P Value \\
\hline Between Groups & 11.73 & 6 & 1.955 & 1.023 & 0.409 \\
\hline Within Groups & 941.878 & 493 & 1.911 & 1.034 & 0.49 \\
\hline Total & 953.608 & 499 & 3.866 & 2.057 & 0.899 \\
\hline
\end{tabular}

\begin{tabular}{|c|c|c|c|c|}
\hline \multirow{2}{*}{ Parameter } & \multicolumn{3}{|c|}{ Present study(500) } \\
\cline { 2 - 5 } & \multicolumn{2}{|c|}{ Male } & \multicolumn{2}{c|}{ Female } \\
\cline { 2 - 5 } & Right & Left & Right & Left \\
\hline $\begin{array}{c}\text { Mean length of } \\
\text { frontal horn } \\
(\mathrm{mm})\end{array}$ & 29.8 & 31.1 & 28.9 & 29.9 \\
\hline SD & \pm 2.5 & \pm 2.5 & \pm 2.3 & \pm 2.3 \\
\hline
\end{tabular}

Table 5: Showing comparison of the length of frontal horn between different studies.

\begin{tabular}{|c|c|c|c|c|c|c|c|c|c|c|c|c|}
\hline \multirow{2}{*}{ Parameter } & \multicolumn{2}{|c|}{ D'Souza et al study (1000) } & \multicolumn{3}{c|}{ Brij et al study (358) } & \multicolumn{3}{c|}{ Moawia study (152) } \\
\cline { 2 - 16 } & \multicolumn{2}{|c|}{ Male } & \multicolumn{2}{c|}{ Female } & \multicolumn{2}{c|}{ Male } & \multicolumn{2}{c|}{ Female } & \multicolumn{2}{c|}{ Male } & Female \\
\cline { 2 - 16 } & Rt & Lt & Rt & Lt & Rt & Lt & Rt & Lt & Rt & Lt & Rt & Lt \\
\hline $\begin{array}{c}\text { Mean length of } \\
\text { frontal horn (mm) }\end{array}$ & 27.4 & 27.8 & 25.5 & 25.8 & 25 & 26.2 & 25.3 & 26.5 & 28.5 & 28.5 & 26.16 & 26.2 \\
\hline SD & \pm 3.6 & \pm 3.7 & \pm 3.3 & \pm 3.5 & \pm 3.1 & \pm 2.9 & \pm 3.5 & \pm 3.3 & \pm 3.8 & \pm 3.8 & \pm 4.2 & \pm 4.2 \\
\hline
\end{tabular}

\section{DISCUSSION}

Length of frontal horn by CT scan: In the present study, mean length of frontal horn in males was found to be $28.5 \mathrm{~mm}$ and $30.3 \mathrm{~mm}$ on right and left sides respectively. While in females it was found to be $25.9 \mathrm{~mm}$ and 29.6 $\mathrm{mm}$ on right and left sides respectively. The mean length of frontal horn was found to be more in males as compared to females and was also more on the left side as compared to the right side.

Dsouza and Natekar in their study conducted in 2007, found the mean length of frontal horn in males to be $27.4 \mathrm{~mm}$ on right side and $27.8 \mathrm{~mm}$ on left side while in females to be $25.5 \mathrm{~mm}$ and $25.8 \mathrm{~mm}$ on right and left sides respectively [7].

Brij Raj Singh et al in their study conducted in
2014 found the mean length of frontal horn in males to be $25.0 \mathrm{~mm}$ on right side and $26.26 \mathrm{~mm}$ on left side while in females it was $25.3 \mathrm{~mm}$ on right side and $26.5 \mathrm{~mm}$ on left side [8].

Moawia Gameraddin, Abdulrahim, Amir Ali \& Mosleh in their study conducted in 2015 found the mean length of frontal horn in males to be $28.5 \mathrm{~mm}$ on right and left sides, while in females it was $26.16 \mathrm{~mm}$ and $26.17 \mathrm{~mm}$ on right and left sides respectively [9].

The finding of present study correlated well with the findings of the study conducted by Moawia et al. However the readings obtained by D Souza and Brij et al were less as compared to the present study. This could be due to the limited age group of the sample population studied by D Souza and Brij et al. 


\section{CONCLUSION}

The present study defined the length of frontal horn of lateral ventricles of brain by CT which could have clinical correlations in diagnosis, treatment and management of neurological conditions.

Differences were observed between the mean lengths of frontal horn on right and left sides and also between males and females, that the length was found to be more in males and on left side, but the differences were not statistically significant. Age wise analysis showed the mean length of frontal horn to increase gradually from age group 30-39years onwards with a maximum value in the age group 70-79 years on both right and left sides by $\mathrm{CT}$, but again there was no any statistically significant difference between different age groups.

\section{Conflicts of Interests: None}

\section{REFERENCES}

[1]. Williams PL, Bannister LH, Berry MM, Collins P, Dyson M, Dussek JE, et al. Gray's Anatomy. The Anatomical basis of Medicine and Surgery. $38^{\text {th }}$ ed. Edinburgh: Elsevier Churchill Livingstone; 1995. pp. 1205-9.

[2]. Srijit D, Shipra P. Anatomical study of anomalous posterior horn of lateral ventricle of brain and its clinical significance. British Lek Listy 2007; 108(9):422-4.

[3]. Aziz, Aamer, Hu, Qing M, Nowinski, Wieslaw L. Morphometric analysis ofcerebral ventricular system from MR images. Med Imag 2004;5369:574-82.
[4]. Asthari M, Zito JL, Gold BI, Lieberman JA, Borenstein MT, Herman PG. Computerised volume measurement of brain structure. Invest Radio 1990 Jul; 25(7):798805.

[5]. Rohlfing T, Sullivan EV, Pfefferbaum A. Deformationbased brain morphometry to track the course of alcoholism: differences between intra-subject and inter-subject analysis. Psychiatry Res 2006 Mar 31;146(2): 157-70.

[6]. Torkildsen A. The gross anatomy of the lateral ven tricles. J Anatomy 1934 Jul; 68:480-91.

[7]. D'Souza e Dias Medora C. \& Natekar Prashant E. Morphometric Study Of The Ventricular System Of Brain By Computerised Tomography. Goa Medical College, Goa. J. Anat. Soc. India 2007;56(1):19-24.

[8]. Brij Raj Singh, Ujwal Gajbe, Amit Agrawal, Anilkumar Reddy Y, Sunita Bhartiya.VENTRICLES OF BRAIN: A MORPHOMETRICSTUDY BY COMPUTERIZEDTOMOGRAPHY. Int J Med Res Health Sci. 2014;3(2): 381-387.

[9]. Moawia Gameraddin, Abdalrahim Alsayed, Amir Ali, Mosleh Al-Raddadi. Morphometric Analysis of the Brain Ventricles in Normal Subjects Using Computerized Tomography . Open Journal of Radiology, 2015;5:13-19.

How to cite this article:

Shaikh Shamama Farheen, S B Sukre. MORPHOMETRIC STUDY

OF FRONTAL HORN OF LATERAL VENTRICLE BY COMPUTERISED

TOMOGRAPHY. Int J Anat Res 2017;5(3.1):4063-4066. DOI:

10.16965/ijar.2017.250 